Dmitry N. Kiselev

\title{
Organization of the social and economic space of territories employing cluster and network structures
}

\section{KEYWORDS}

socio-economic space;

clusters;

economic network;

cluster-network structures;

cluster-network model

\section{ABSTRACT}

Successful development of the regional economy is impossible without creating special conditions and forming a mechanism ensuring balanced and sustainable socio-economic development of the regions of the Russian Federation. To achieve the goals outlined above, the authors propose a solution based on the creation of a conceptually new model for organizing the socio-economic space of territories through cluster-network structures designed to improve the life quality of the population and increase the competitiveness of the regional economy.

Various methodological approaches and a number of general scientific and unique research methods were used, including the system-structural approach, as well as analysis, synthesis, generalization, comparison, and modeling.

As a result of the research, the advantages of the cluster-network model, in contrast to the cluster model of organizing economic interactions, are justified. A conceptual model of the organization of socio-economic space through cluster-network structures is presented. The organizational and economic mechanism of functioning of cluster-network formations is developed. It is established that the cluster-network model, in contrast to the widely used cluster model, increases the competitiveness of the economy on a larger scale due to the multiplicative effect of clustering and networking processes.

The innovations proposed in this paper are intended to complement or expand existing scientific approaches to clustering and networking of the economy both at the regional and interregional levels.

Kiselev, D. N. (2020). Organization of the social and economic space of territories employing cluster and network structures. Economic consultant, 29 (1), 12-20. doi: 10.46224/ecoc.2020.1.2 


\section{INTRODUCTION}

$\mathrm{T}$ he main problem of the functioning and development of the Russian economy as a system of interacting regions is the exceptional heterogeneity and uneven development of the socio-economic space.

The problem of spatial heterogeneity initiates the creation of a new paradigm of territorial organization and accelerated transformation of socio-economic space, which requires structural changes in the economy and contributes to improving the economic efficiency of territories, stimulating positive and overcoming negative trends in socioeconomic development based on the effective and rational use of existing potential in the Russian regions.

The regions currently face a severe task of economic efficiency of their activities. At the same time, the choice of a competitive model of regional development is mainly determined by the organizational economy structure.

One of the possible ways to overcome the existing problems of territorial development and the upcoming transformation is to build a new model of the organization of socio-economic space based on cluster-network structures (CNSs), each of which is a network relationship of the spatial distribution of economic entities that make up a network of relationships and interactions of structural elements of regional economies of adjacent territories both inside and outside of clusters [1].

\section{DEGREE OF PROBLEM DEVELOPMENT}

A significant contribution to the study of the clustering of the regional economy was made by the provisions of fundamental and applied research of domestic and foreign scientists. These works include the works of foreign authors: Man [2], Porter [3], Enright [4], Ketels [5], Engel [6] and others, reflecting the issues of the economic cluster approach in the regional aspect; in particular, their works substantiate the advantages and positive impact on the regional economy of territorial clusters.

The following works of domestic scientists must be noted: Kutsenko [7], Granberg [8], Abashkin [9], Alenkina [10], Stryabkova [11], in which the problem related to the mechanisms, tools for creating and functioning of industrial, territorial and innovative clusters in the regions is solved. The results of their research indicate that in the regions, the forms and mechanisms of organizing and supporting innovation activities as clusters are formed, emerging, developed, adapted, and tested.

The works of Blau and Scott [12], Homans [13], and Emerson [14] are devoted to the issues of networks as a representation of structures and exchange flows. Summarizing the theoretical conclusions of their work, one can define a network as a social group focused on achieving interrelated specific goals and forming highly formalized structures. The representation of 
social networks as social capital is inherent in the works of Bourdieu [15], Jackson [16], Gradoselskaya [17]. These works explain that hierarchy ceases to be the dominant principle of the organization of economic structures, and the structures themselves no longer exist in their usual form.

Studies containing the main characteristics of the network organization and elements of the theory of economic interactions were conducted by Gui and Sugden [18]. In the works of Grewal [19], Yamashita and Eades [20], the relationship between the formation of the network economy and the globalization of the economy is considered. These studies indicate that the processes of globalization have an impact on clusters and economic networks, helping to increase their competitiveness in the world market.

The works of Shibaeva [21], Smorodinskaya [22] are devoted to the problems of networking of economic interactions. In particular, Shibaeva asserts that the processes of networkizaction activate interactions both within and between economic entities and lead to the emergence of a new network economy [21]. According to Smorodinskaya, the complexity of the structure and increased plasticity of systems during networkization is intended to obtain the ability to self-development based on continuous updates, i.e., to make economic growth innovation-oriented, and, consequently, more stable [22].

Despite a significant number of works devoted to the study of clustering of socioeconomic space and the network approach in the economy, the problem of spatial and economic transformation, smoothing the spatial polarization of the regional economy and socio-economic differentiation of regions, remains relevant, which necessitates a further search for solutions by selecting and developing various tools and mechanisms that contribute to the territorial integration of Russian regions.

\section{MATERIALS AND METHODS}

The theoretical and methodological basis of the research is the works of foreign and domestic scientists-economists, who reveal the issues of theory and practice of the formation and development of economic clusters and networks.

Various methods of general scientific knowledge (analysis, synthesis, generalization, comparison, modeling) and a set of specialized methods were used in the research: systemstructural approach, economic-statistical analysis, and synthesis.

The information and empirical base of the research consist of materials from the Ministry of Economic Development of the Russian Federation, legislative and regulatory documents of federal and regional authorities, methodological and analytical materials of the National Cluster Observatory, and Internet resources. 


\section{RESEARCH RESULTS}

CNSs that represent the network relationship of spatial placement of economic entities in adjacent territories both inside and outside the clusters allow organizing the socio-economic space of the territories in such a way that the process of collective interaction is enhanced creating favorable conditions for the development of the corporate, network, and local megastructure and megaeconomic territories where they are based. It creates a propagation medium and active centers of global economic growth, leading to a cumulative effect of the internal and external aspects, which in turn contributes to increased productivity, innovative activity and development of organizations included in the cluster-network structure, increases the intensity of development of small and medium businesses thus intensifying the investment attraction and, as a consequence, ensures increased revenues to the state budget at all levels, improves the situation of individual industries and regions and the country as a whole.

A study of the literature of the last decade devoted to clustering and networking processes has shown that clusters not only consist of different types of networks but can also form a single network into a broader territory [23].

The cluster-network model is, first of all, a new management technology that allows increasing the efficiency of functioning of territorial entities. This is a complex multi-level, internally differentiated open system, through which a favorable socio-economic environment is formed [24], ensuring the implementation of three main principles of territorial development: stability, proportionality, and balance [25]. All these properties of the system are interconnected with each other and must be present simultaneously at any time. Sustainability involves maintaining the reproductive potential of cluster structures over a long period. Proportionality provides a functional and efficient reallocation of resources within clusters and between clusters over network connections. The balance is determined by the network interactions of all economic systems in the cluster-network structure of the region.

In the opinion of the authors, "organization of socio-economic space through CNSs" is a purposeful process of formation, functioning, and development of closely intertwined via circulating information and resource flow CNSs that form ordered integrity of effectively managed space by various economic entities, designed to improve the quality of life and increase the competitiveness of the territories' economy. At the same time, the cluster-network mechanism of the organizational structure of the socio-economic space has a territorial and sectoral binding.

In contrast to the widely used cluster model for organizing economic interactions, the clusternetwork model has several additional advantages. In the authors' opinion, the cluster-network model of organizing economic interactions provides an increase in the competitiveness of the economy on a larger scale compared to the cluster model, and higher results of economic activity due to the multiplicative effect of clustering and networking processes.

The proposed concept of the organization model of the socio-economic space via CNSs includes the definition of the stages of organization, goals, objectives, and principles of 
organization of each stage, as well as the structural elements of the organization and their functional characteristics (Table 1).

Table 1 A conceptual model of the organization of socio-economic space through CNSs

\begin{tabular}{|c|c|c|c|c|c|}
\hline \multicolumn{6}{|c|}{ Organization stages } \\
\hline \multicolumn{2}{|c|}{ forming } & \multicolumn{2}{|c|}{ functioning } & \multicolumn{2}{|c|}{ development } \\
\hline \multicolumn{2}{|c|}{$\begin{array}{l}\text { 1. Appearance, adaptation, and } \\
\text { interaction of cluster elements } \\
\text { 2. The origin of the cluster } \\
\text { core from a group of individual } \\
\text { enterprises united by a single } \\
\text { production chain } \\
\text { 3. Integration of infrastructure } \\
\text { enterprises around the cluster core } \\
\text { 4. Combining research and } \\
\text { educational centers around the } \\
\text { cluster core }\end{array}$} & \multicolumn{2}{|c|}{$\begin{array}{l}\text { 1. The output of the cluster to the } \\
\text { domestic market } \\
\text { 2. Improving technologies, } \\
\text { reducing the cost of production } \\
\text { and, as a result, increasing the } \\
\text { competitiveness of the economy of } \\
\text { the cluster's home region } \\
\text { 3. Entering the foreign market } \\
\text { 4. Organization of network } \\
\text { interaction between subjects, } \\
\text { including the definition of forms } \\
\text { and methods of interaction }\end{array}$} & \multicolumn{2}{|c|}{$\begin{array}{l}\text { 1. Consolidation and integration of } \\
\text { CNSs at the meso-level } \\
\text { 2. Development of forms, methods, } \\
\text { and conditions for multi-channel } \\
\text { resource provision } \\
\text { 3. Creating megaclusters - clusters } \\
\text { based in adjacent regions at the } \\
\text { macroregion level and united by a } \\
\text { single production or industry chain } \\
\text { 4. Cross-border expansion of } \\
\text { megaclusters }\end{array}$} \\
\hline \multicolumn{6}{|c|}{ Goal and objectives of each stage } \\
\hline \multicolumn{2}{|c|}{$\begin{array}{l}\text { Goal: the emergence of economic } \\
\text { clusters } \\
\text { Tasks: } \\
\text { 1) create conditions for the } \\
\text { emergence of a cluster from a } \\
\text { group of individual enterprises } \\
\text { 2) ensure that clusters enter the } \\
\text { domestic market } \\
\text { 3) promote cluster networking }\end{array}$} & \multicolumn{2}{|c|}{$\begin{array}{l}\text { Goal: increasing the region's } \\
\text { competitiveness } \\
\text { Tasks: } \\
\text { 1) expand the system of cluster } \\
\text { relationships with external agents } \\
\text { 2) expand the resource supply } \\
\text { channels through network } \\
\text { interconnections } \\
\text { 3) focus on cluster management } \\
\text { by encouraging a network of } \\
\text { relationships }\end{array}$} & \multicolumn{2}{|c|}{$\begin{array}{l}\text { Goal: consolidate the clusters } \\
\text { and their integration into the } \\
\text { megaclusters } \\
\text { Tasks: } \\
\text { 1) develop multi-channel resource } \\
\text { provision } \\
\text { 2) create a unified information } \\
\text { system } \\
\text { 3) provide conditions for the } \\
\text { development of the mechanism of } \\
\text { CNS functioning } \\
\text { 4) model cluster-network processes } \\
\text { of regional economies }\end{array}$} \\
\hline \multicolumn{6}{|c|}{ Principles of stage organization } \\
\hline \multicolumn{2}{|c|}{$\begin{array}{l}\text { 1. Interactions } \\
\text { 2. Cooperation }\end{array}$} & \multicolumn{2}{|c|}{ 1. Competitions Rivalries } & \multicolumn{2}{|c|}{$\begin{array}{l}\text { 1. Universal and mutual support } \\
\text { 2. Limitations }\end{array}$} \\
\hline \multicolumn{6}{|c|}{ Structural elements of the organization - the result of each stage and the functional characteristics } \\
\hline & $\begin{array}{c}\text { functional } \\
\text { characteristic }\end{array}$ & & $\begin{array}{c}\text { functional } \\
\text { characteristic }\end{array}$ & & $\begin{array}{c}\text { functional } \\
\text { characteristic }\end{array}$ \\
\hline $\begin{array}{l}\text { 1. Components } \\
\text { of external } \\
\text { influence } \\
\text { 2. Components } \\
\text { of self-regulation }\end{array}$ & $\begin{array}{l}\text { Provide } \\
\text { economic, } \\
\text { institutional, } \\
\text { informational } \\
\text { and } \\
\text { coordinating } \\
\text { impact on } \\
\text { emerging } \\
\text { clusters }\end{array}$ & $\begin{array}{l}\text { 1. Components } \\
\text { of external } \\
\text { influence } \\
\text { 2. Components } \\
\text { of self-regulation }\end{array}$ & $\begin{array}{l}\text { Cluster } \\
\text { evolution via the } \\
\text { management of } \\
\text { state regulation } \\
\text { tools, the expert } \\
\text { community and, } \\
\text { as a result, the } \\
\text { development } \\
\text { of the self- } \\
\text { regulatory } \\
\text { component }\end{array}$ & $\begin{array}{l}\text { 1. Components } \\
\text { of external } \\
\text { influence } \\
\text { 2. Components } \\
\text { of self-regulation }\end{array}$ & $\begin{array}{l}\text { Contradictions } \\
\text { in the cluster- } \\
\text { forming core, } \\
\text { leading to } \\
\text { the progress } \\
\text { or regression } \\
\text { of the CNS } \\
\text { development }\end{array}$ \\
\hline
\end{tabular}

The analysis of Table 1 allowed concluding that the formation, functioning, and development of CNSs are carried out in stages, each with specific goals, objectives, and organization principles. 
CNS structural elements are represented by components of external influence and selfregulation, which have different functional characteristics depending on the stage. Thus, at the stage of CNS formation, the components of external influence and self-regulation provide economic, institutional, informational, and coordinating impact on the emerging clusters. At the stage of functioning, clusters are evolving through the management of state regulation tools, the expert community, and, as a result, the development of a self-regulatory component. The development stage is characterized by the presence of contradictions in the cluster-forming core, leading to progress or regression of the CNS development.

It can be assumed that within the framework of the cluster-network model, it becomes possible to create an effective self-developing and self-supporting economic system that will not only ensure the active socio-economic development of regions but also solve the problems of their territorial disunity.

Since modern cluster theory does not consider economic clusters as system objects, the mechanism of their functioning remains unclear. The authors share the opinion of Reisberg and a number of other scientists who believe that the "economic mechanism" is "a set of processes, organizational structures, specific forms and methods of management, as well as legal norms that are used to implement the economic laws operating in specific conditions, the process of reproduction" [26].

In the authors' opinion, the concept of functioning of cluster formations (networks) is in the consistency of all the basic elements of the network itself. Goals and objectives set the necessary resources for their development, the configuration of the company's development, and the types of interaction between its structural divisions, as well as ways to achieve them.

Figure 1 Structural elements of the organizational and economic mechanism of functioning of cluster-network entities (compiled by the author)

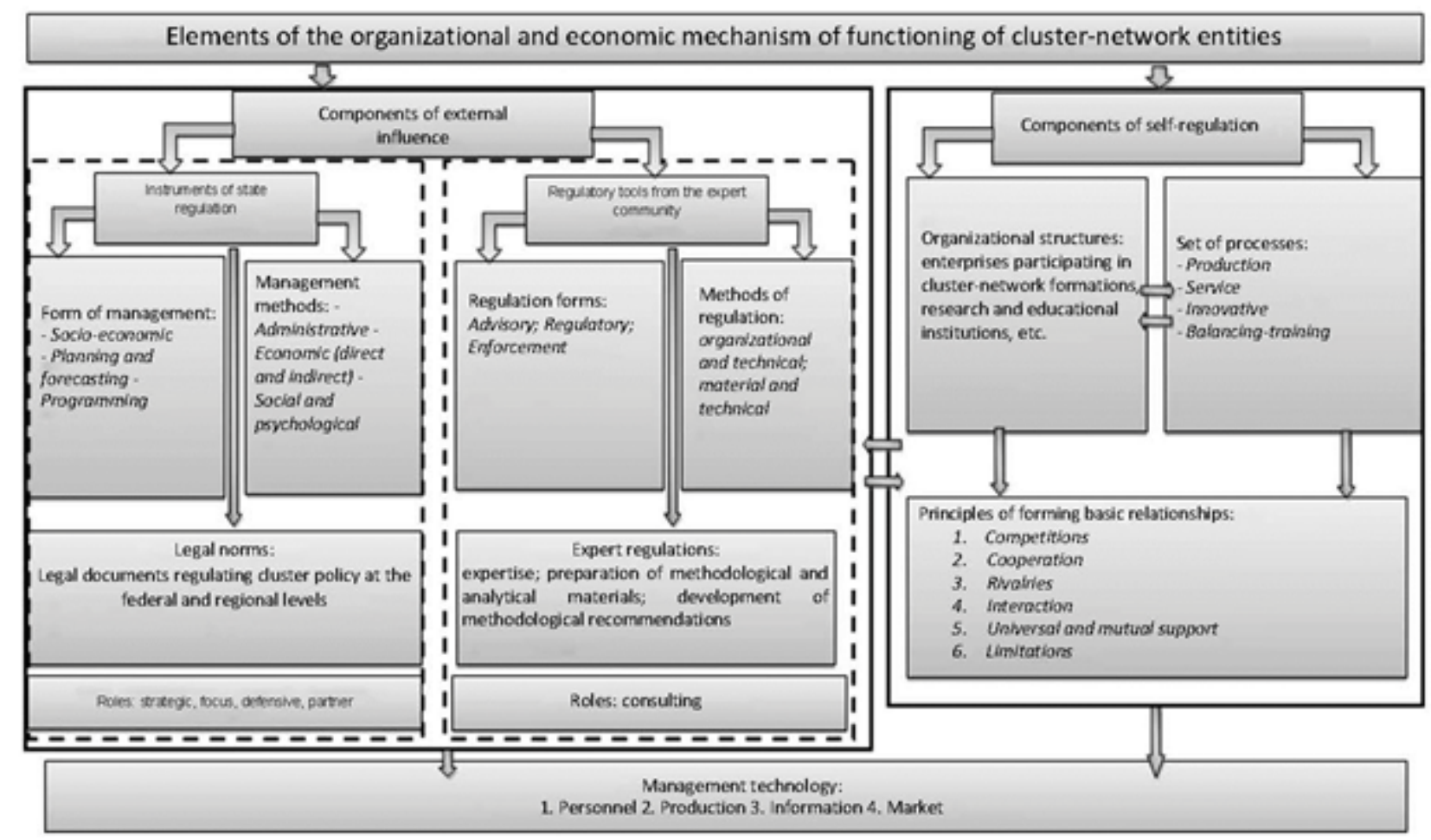


In turn, the resources used must correspond to the selected structure and strategy for the development of network integration in terms of their characteristics, volume, and content [27]. Besides, the structure and strategy for developing network integration must be consistent with each other. If the balance between the basic components of the integration structure is disturbed, the company's goals and objectives are not fully achieved, and, as a result, the existence and activity of companies in the market are threatened.

The development and adaptation of the organizational and economic mechanism for the functioning of cluster-network entities consist of the balance of all its main elements, indicated in Figure 1 [28].

\section{DISCUSSION OF RESULTS}

The study of the mechanism of functioning of cluster formations as network structures allows drawing the following conclusions:

1. The structure of the mechanism of functioning of cluster-network entities consists of components of external influence and self-regulation, including a set of processes, organizational structures, specific forms, management methods, legal norms, and expert regulations. External influence is carried out through the use of tools of state regulation and the expert community. In turn, the self-regulation of cluster-network formations is based on the principles of the formation of primary links and a set of processes.

2. An essential aspect of cluster development is the presence of a contradiction between a pair of components that are a cluster-forming core, which can unfold in different modes that specify one of the directions of cluster development - progress or regression.

3. The essential relationships in clusters are those of direct/pathological support and direct/pathological restriction that arise from the distribution of system-cluster resources, such as the supply and demand of products and services produced by the cluster components. For supply and demand in cluster-network entities, competition between competing components occurs, which is supplemented by cooperation between cooperating components.

4. Identifying the nature of relationships and contradictions between cluster components allows selecting relevant management measures that contribute to the productive development of both cooperative relationships and intra-cluster contradictions.

\section{CONCLUSION}

Thus, the cluster-network model is, first of all, a new management technology that allows increasing the efficiency of functioning of territorial entities. This is a complex multi-level, internally differentiated open system, through which a favorable socio-economic environment 
is formed, ensuring the implementation of three main principles of territorial development: stability, proportionality, and balance.

The cluster-network model, in contrast to the widely used cluster model, increases the competitiveness of the economy on a larger scale due to the multiplicative effect of clustering and networking processes.

The described mechanism of cluster functioning makes it possible not only to understand the nature of relations between the structural parts of the cluster but also to reflect the aspects of their development, implying the formation of new components and, accordingly, new inter-component relationships and contradictions. The above-noted allows providing further improvement of the functioning mechanism of cluster formation and obtaining positive socioeconomic effects such as economic growth, improvement and development of the resource base, improving the reproductive structure of the innovation system, acceleration of scientific and technological progress and eventually improved economic competitiveness and welfare.

\section{REFERENCES}

1. Kiselev, D.N., \& Feraru, G.S. (2018). Development of the Concept of Cluster-Network Organization of Socio-Economic Space of Territories. Questions of the Regional Economy, 3 (36), 97-103.

2. Man, A.P. (2004). The Network Economy: Strategy, Structure, and Management. Northampton: Edward Elgar. (p. 382).

3. Porter, M.E. (1998). The Competitive Advantage of Nations: With a New Introduction (10th ed.). N.Y.: The Free Press, Palgrave. (p. 855).

4. Enright, M.J. (2003). Regional Clusters: What We Know and What We Should Know. In J. Brucker, D. Dohse, \& R. Soltwedel (Eds.), Innovation Clusters and Interregional Competition. Advances in Spatial Science (pp. 99-129). Berlin, Heidelberg: Springer.

5. Ketels, C.H.M. (2017, June). Cluster Mapping as a Tool for Development. Working Paper. (p. 52).

6. Engel, J.S. (2016). Global Clusters of Innovation: Entrepreneurial Engines of Economic Growth Around the World. Edward Elgar Publishing. (p. 432).

7. Kutsenko, E.S. (2015). Pilot Innovative Territorial Clusters of Russia: A Model of Sustainable Development. Foresight, 9 (1), 32-55.

8. Granberg, A.G. (2009). Modeling of Spatial Economic Development. Strategic Planning in Regions and Cities of Russia, 9, 32-34.

9. Abashkin, V.L., Artemov, S.V., Islankina, E.A. et al. (2017). Cluster Policy: Achieving Global Competitiveness. Moscow: NRU HSE. (p. 324).

10. Alenkina, E.A., \& Fiyaksel, E.A. (2015). Glocalization of Innovations: The Role of Clusters and the International Context in Regional Development. Innovations, 11 (205), 64-74.

11. Stryabkova, E.A. (2016). Improving Regional Competitiveness Based on and Methodology (Ph.D. Thesis Abstract). Belgorod. (p. 38). 
12. Blau, P.M., \& Scott, W.R. (1962). Formal Organizations: A Comparative Approach. San Francisco: Chandler Pub. Co. (p. 344).

13. Homans, G.C. (1950). The Human Group. Harcourt: Brace \& World. (p. 484).

14. Emerson, R.W. (1982). Selected Essays. Penguin Classics. (p. 420).

15. Grenfell, M.J. (2014). Pierre Bourdieu: Key Concepts (2nd ed.). Routledge. (p. 303).

16. Jackson, M.O. (2010). Social and Economic Networks. Princeton University Press. (p. 504).

17. Gradoselskaya, G.V. (2004). Network Measurements in Sociology: Textbook. Moscow: Novyi uchebnik. (p. 248).

18. Gui, B., \& Sugden, R. (2005). Economics and Social Interaction: Accounting for Interpersonal Relations. Cambridge University Press. (p. 318).

19. Grewal, D.S. (2008). Network Power: The Social Dynamics of Globalization. Yale University Press. (p. 416).

20. Yamashita, S., \& Eades, J.S. (2002). Globalization in Southeast Asia: Local, National, and Transnational Perspectives. Berghahn Books. (p. 272).

21. Shibaeva, T.A. (2018). Evaluation of Cluster-Network Structures of Regional Economy. Fundamental Research, 3, 84-89.

22.Smorodinskaya, N.V. (2015). Globalized Economy: From Hierarchies to Network Structure. Moscow: IE RAS. (p. 344).

23. Bek, M.A., Bek, N.N., Buzulukova, E.V. et al. (2014). Methodology of Research of Network Forms of Business Organization. Moscow: Publishing House of Higher School of Economics. (p. 446).

24.Plotnikova, T.N., \& Shibaeva, T.A. (2016). Cluster-Network Model of Regional Development. Fundamental research, 2-1, 193-196.

25. Danko, T.P., Klyagin, A.V., \& Kutsenko, E.S. (2009). Clusters in a Competitive National Economy: A Collective Monograph. In Interaction Marketing: Concepts, Strategies, Effectiveness (pp. 534-537). Saint Petersburg.

26. Reisberg, B.A., Lozovsky, L., \& Starodubtseva, E.B. (2008). Modern Economic Dictionary (6th ed., rev. and add.). Moscow: INFRA-M. (p. 451).

27. Bulgakov, I.N., \& Remizov, D.G. (2010). Network Economy in Russia: Fundamentals of Formation and Development. Problems of the Regional Economy, 34, 23-29.

28. Kiselev, D.N., \& Feraru, G.S. (2019). Mechanism of Functioning of Cluster-Network Structures. Bulletin of the Altai Academy of Economics and Law, 1, 170-176.

\section{INFORMATION ABOUT THE AUTHOR}

1. Dmitry N. Kiselev (Russia, Belgorod) - Postgraduate student. Belgorod State National Research University. E-mail: mr.dmitriykiselev@gmail.com 